\title{
MOTIVASI, KEPUASAN, KARAKTERISTIK, KEPEMIMPINAN DAN KEADILAN TERHADAP KOMITMEN ORGANISASI
}

\author{
Golan Hasan \\ Universitas Internasional Batam, Indonesia \\ golan.gh51@gmail.com
}

\begin{abstract}
Abstrak: Motivasi, Kepuasan, Karakteristik, Kepemimpinan dan Keadilan Terhadap
Komitmen Organisasi. Dilaksanakannya penelitian ini adalah untuk memberikan analisa serta pengaruh motivasi, kepuasan, karakteristik kepemimpinan, dan keadilan dalam organisasi serta komitmen dalam organisasi bagi karyawan bank swasta dengan jumlah pekerja yang cukup banyak. Penelitian ini terfokus pada karakterisitk kerja, kepemimpinan serta keadilan suatu organisasi sehingga memberikan pengaruh dalam komitmen organisasi. Untuk sampel yang dilakukan adalah sebanyak 200 karyawan yang diambil dari 5 (lima) bank swasta yang terdapat di Batam. Sampel yang bisa digunanakan sebanyak 124, serta mempergunakan PLS (Partial Least Squares). Kesimpulan dari penelitian ini menunjukkan adanya pengaruh yang signifikan antara motivasi kerja, hasil kepuasan kerja dan pengaruh non-signifikan karakteristik kerja, kepemimpinan serta keadilan suatu organisasi berpengaruh bagi komitmen organisasi.
\end{abstract}

Kata kunci: Motivasi, Kepuasan, Kepemimpinan, Keadilan, Organisasi

\begin{abstract}
MOTIVATION, SATISFACTION, CHARACTERISTIC, LEADRESHIP AND JUSTICE ON ORGANIZATIONAL COMMITMENTS. The implementation of this research is to provide analysis and the influence of motivation, satisfaction, characteristics, leadership and justice in organizations and commitments in organizations for employees of private banks with a considerable number of workers. This research focuses on the characteristics of work, leadership and fairness of an organization so that it gives influence in organizational commitment. For the samples to be carried out are 200 employees taken from 5 (five) private banks located in Batam. The samples can be used as many as 124, and using PLS (Partial Least Squares). The conclusions from this study indicate a significant influence between work motivation, work satisfaction results and non-significant effects of work characteristics, leadership and fairness of an influential organization for organizational commitment.
\end{abstract}

Keyword: Motivation, Satisfaction, Leadership, Justice, Organization

\section{PENDAHULUAN}

Banyaknya perusahaan khususnya dalam dunia kerja yang berkaitan dengan dunia perbankan, permasalahan komitmen karyawan adalah hal yang penting sebab mempunyai hal yang akan berhubungan dengan kinerja karyawan, pada bagian lain kinerja karyawan dapat dipengaruhi oleh banyak hal antara lain karakterisitk kerja, motivasi, komitmen organisasi serta kepuasan kerja yang terutama pada suatu lembaga keuangan. Karyawan yang bekerja di salah satu bank memiliki masalah yang cukup mendasar dimana dari setiap karyawan yang lain serta karyawan lainnya memiliki komitmen yang berbeda-beda. Pada suatu lembaga keuangan jika komitmen karyawan tinggi dapat meningkatkan kinerja karyawan yang juga tinggi serta dapat menurunkan rendahnya absensi, begitu juga sebaliknya jika komitmen karyawan rendah maka kinerja karyawan juga semakin rendah.

Variabel komitmen adalah hal yang dapat memprediksi perilaku karyawan secara teratur dalam dunia kerja khususnya permasalahan dalam absensi. Suatu Komitmen karyawan dalam Perbankan juga memiliki hubungan yang positif dalam pekerjaan, bila tidak ada komitmen karyawan pada suatu 
organisasi maka kinerja dapat menjadi lemah serta akhirnya dapat mengakibatkan hal yang sia-sia terhadap organisasi.

Hal yang pernah terjadi pada salah satu perusahaan terbuka yang terdapat di Batam, masalah yang terjadi adalah bagaimana pemilik perusahaan tersebut merubah kepemilikan, akibatnya lebih dari 150 orang pekerja bersama-sama melakukan tuntutan untuk dapat kenaikkan gaji yang mana selama ini tidak sesuai dengan undang-undang. Perusahaaan tersebut tidak menindak dengan tegas, serta betindak tetap mempertahankan karyawan dengan tidak memberikan sangsi PHK, agar komitmen karyawan pada perusahaan dapat terus meningkat. Harapan yang diinginkan oleh perusahaan adalah dengan tidak menindak lanjuti mogok kerja karyawan tersebut maka karyawan semakin berkomitmen. Pekerja masih dapat diberikan kesempatan untuk dapat melanjukan hubungan kerjanya dengan mekanisme yang sudah ada serta dikomunikasikan sebelumnya. (Kompas.com).

Hal yang dapat mempengaruhi dalam suatu komitmen adalah motivasi kerja, pekerja yang tidak memiliki motivasi kerja selalu mempunyai tingkat kinerja yang kurang baik, rasa ketidakpuasan dalam bekerja yang dapat menyebabkan komitmen kerja terhadap komitmen organisasi cukup rendah. Peneliti-peneliti terdahulu sudah melakukan penelitian yang mempengaruhi motivasi kerja terhadap komitmen organisasi ,diantaranya Warsi, Fatima, Salsabila (2009) Choong, wong dan Lau (2011) Salami (2008), Samad (2011), Khan, Ali, Razi dan Asghar (2011) Zahra,Tahere Asma dan Fateme (2012).

Hal lain yg juga dapat memberikan pengaruh dalam komitmen adalah jika kepuasan kerja karyawan terpenuhi atau ketidak inginan karyawan terhadap pekerjaan. Jika dalam lingkungan kantor bagi seorang karyawan tidak mendapatkan apa yang diharapkan antara lain peluang promosi yang adil, penghasilan yang baik, sahabat serta pimpinan yang menyenangkan dan kenyamanan terhadap pekerjaan itu sendiri adalah sikap umum bagi karyawan sebagai perbedaan dengan maksimalnya upah yang diterima karyawan serta begitu banyak yang akan diterima nanti. Maka kepuasan kinerja berpengaruh positif dalam komitmen organisasi. Fungsi dan kedudukan karyawan juga dapat mempengaruhi kepuasan kerja, jika karywan yang memiliki jabatan yang lebih tinggi maka mereka akan merasa lebih puas dikarenan memiliki kekuasaan yang lebih besar, dalam bekerja lebih memiliki variasi serta mampu memberikan nilai untuk karyawan di bagian yang lebih rendah, juga memiliki kebebasan dalam memutuskan suatu permasalahan dalam pekerjaan, bernading terbalik dengan karyawan yang memilik kepangkatan yang lebih rendah, mereka cenderung memiliki ketidaknyamanan serta mulai mengalami kebosanan karena pekerjaan mereka tidak menantang serta tanggung jawab yang lebih kecil, hal ini biasanya terjadi pada pekerja yang mempunyai pendidikan yang cukup tinggi sementara dalam pekerjaan mereka mendapatkan bagian yang lebih rendah. Kepuasan kinerja dapat memberikan pengaruh dalam pekerjaan dengan asumsi jika karywan akan mampu memberikan yang terbaik di lembaga perbankan tempat mereka bekerja. Peneliti terdahulu sudah melakukan penelitian mengenai kepuasan kerja dimana memberikan pengaruh bagi komitmen organisasi yaitu, Martin dan Shore (1989), Madupali, Boles, Rutherfood dan wood (2007) Salami (2008), Fatima,Warsi Sahibzada (2009, Narcio, Liu (2009) Malik (2010) Nawab dan Bhatti (2011) Kadir, Kamaruddin, Salim (2012), Isran, Shan, Memon (2012) Asma, Fateme, Zahra, Tahere (2012). Ma'alip, Yahya, Ain (2012). Karekteristik pekerjaan dapat juga memberikan pengaruh komitmen dari seorang karyawan di bank, sangatlah jelas jika jenis pekerjaan dan jika pekerjaan tersebut 
semakin menarik buat seorang karyawan, maka semakin tinggi juga komitmen pekerja terhadap bank dimana karyawan tersebut bekerja.

Penelitian terdahulu juga sudah melakukan percobaan dalam karakteristik pekerjaan dimana peneliti terdahulu memberikan analisa pengaruhnya terhadap komitmen organisasi. Para peneliti terdahulu tersebut adalah; Ramay, Bashir (2008) Norcio, Liu (2009) Sriwidodo dan Haryanto (2009) Djastuti (2012). Hal yang cukup penting adalah keadilan dalam organisasi, sebab perlakuan adil yang diterima pekerja dalam pekerjaannya, dapat memberikan pengaruh terhadap komitmen karyawan tersebut di perbankan ditempat karyawan tersebut bekerja. Banyak hal yang menyimpang seperti datang tidak tepat waktu, tidak memgikuti perintah atasan, mempergunakan fasilitas dan barang perusahaan diluar wewenang dan diluar jam kerja, hal ini merupakan bentuk penyimpangan yang dilakukan secara sadar oleh karyawan dan dapat menggangu kinerja perusahaan ditempat karywan tersebut bekerja.

Keadilan dalam suatu orgnisasi juga sudah dilakukan dan diteliti pengaruhnya terhadap komitmen organisasi oleh para peneliti terdahulu. Peneliti terdahulu antara lain Naeem dan Malik (2001), Rhoades, Armeli, Eimberger (2001) Hassan (2002), Zafar dan Chunghtai (2006), Magoshi dan Chang (2009) Liao, Xia Chang (2010), Lee, Crow dan Joo (2011) Susanti Jakopec (2012) Haley, Fint Mcnally (2012), Kathairi, Sulliman (2013).

Salah satu yang juga memiliki pengaruh yang besar terhadap komitmen karyawan adalah kepemimpinan. Nowack (2004) memberikan kesimpulan bahwa pekerja yang memiliki atasan dengan kelakuan yang kurang baik, berakibat bagi karyawan tersebut untuk cenderung lebih tinggi keluar dari suatu organisasi. Dalam hal ini kepemimpinan sudah terlebih dahulu diteliti pengaruhnya terhadap komitmen organisasi oleh para peneliti terdahulu. Para peneliti terdahulu antara lain; Craword (2004), Bhatia, Avolio, Koh, Zu (2004) Hasmi, Naqvi, Raza, Zeehshan dan saikh (2011) Susan dan Jakope (2012) Ahmadi, Zihrabi (2012) dan Palon, Behery Hussain (2012).Tujuan dalam penelitian ini adalah: a) Mengetahui pengaruh positif Motivasi Kerja terhadap Komitmen Organisasi, b) Mengetahui pengaruh positif Kepuasan Kerja terhadap Komitmen Organisasi, c) Mengetahui pengaruh positif Karakterisitik Pekerja terhadap Komitmen Organisasi, d) Mengetahui pengaruh positif Kepemimpinan terhadap Komitmen Organisasi, dan e) Mengetahui pengaruh positif Keadilan dalam Organisasi terhadap Komitmen Organisasi.

Berdasarkan penelitian yang telah dilakukan oleh Salami (2008), yang menyatakan bahwa ada hubugan positif yang signifikan antara komitmen organisasi dengan motivasi atas sebuah pencapaian. Sama dengan penelitian yang telah dilakukan oleh Samad (2011), bahwa salah satu faktor yaitu motivasi memberikan pengaruh signifikan terhadap komitmen organisasi. Penelitian yang dilakukan oleh Wong, Choong dan Lau (2011), Faktor yang dapat memberikan pengaruh terhadap komitmen organisasi pengajar di salah satu Universitas swasta di Malaysia adalah Motivasi Kerja, adanya hubungan yang signifikan motivasi kerja memberikan pengaruh terhadap komitmen organisasi dan variasi komitmen organisasi.

Pada penelitian yang juga dilakukan oleh Razi, Khan, Asghar dan Ali (2011) bahwa motivasi yang dilakukan secara signifikan mempengaruhi komitmen organisasi. Hal ini dapat mengkonfirmasi jika komitmen seorang karyawan dalam suatu organisasi dapat dipengaruhi secara positif oleh motivasi kerja. Maka semakin termotivasi seorang pekerja didalam pekerjaannya, maka semakin tinggi tingkat komitmen dalam organisasi tersebut. 
Kepuasan Kerja memberikan sebuah pengaruh yang sangat kuat pada komitmen organisasi, maka dalam bekerja tingkat kepuasan seorang karyawan dalam dunia kerjanya dapat memberikan pengaruh komitmen mereka dalam sebuah organisasi. Penelitian yang telah dilakukan oleh Boles, Madupalli, Rutherford dan Wood (2007) salah satu faktor yang mempengaruhi komitmen organisasi karywan pada bidang penjualan adalah kepuasan kerja. Maka kepuasan kerja adalah salah satu faktor yang yang mempengaruhi variabel tersebut. Faktor kepuasan kerja dengan pelanggan, kepuasan kerja dengan promosi, kepuasan kerja dengan gaji, kepuasan kerja dengan kebijakan perusahaan, kepuasan kerja dengan salah satu pekerjaan, kepuasan kerja dengan pimpinan, dan kepuasan kerja dengan rekan sejawat. Selain itu juga faktor jenis kelamin juga memberikan pengaruh komitmen organisasi karyawan khususnya dalam bidang penjualan. Penelitian yang telah dilakukan oleh Malik (2010), hal yang mempengaruhi komitmen organisasi pengajar sector publik yaitu kepuasan kerja.Kepuasan kerja mempunyai variabel tersebut. Faktor tersebut antara lain adalah bekerja untuk diri sendiri, pengawasan, gaji, rekan sejawat, kesempatan untuk promosi.Tujuan penelitian adalah untuk memahami kepuasan kinerja guru terhadap dimensi pekerjaannya terhadap komitmen organisasi yang dirasakan pada Universitas Sektor Publik di Pakistan. Studi yang dilakukan bertujuan mengeksplorasi sejauh mana guru berkomitmen bagi universitas mereka dan puas dengan pekerjaaan mereka. Menurut penelitian yang dilakukan oleh Igbeneghu (2011), faktor yang mempengaruhi komitmen organisasi adalah locus of control dan kepuasan kerja. Maksud serta tujuan dari penelitian ini adalah untuk memastikan pengaruh locus of control terhadap komitmen organisasi tenaga rekam medis pada Universitas Pendidikan rumah sakit di Nigeria. Pengaruh lain adalah untuk menentukan apakah kombinasi locus of control dan kepuasan kerja secara signifikan dapat memberikan pengaruh komitmen organisasi. Penelitian yang pernah dilakukan oleh Kamaruddin, Salim serta Kadir (2012), bahwa faktor yang memberikan pengaruh dalam komitmen organisasi yaitu; kepuasan kerja, keterlibatan dalam kerja dan perceived organizational support. Tujuan dari penelitian ini yaitu untuk mengetahui pandangan sebagian dosen Universitas di Malaysia, dengan meneliti pengaruh kepuasan kerja, kepuasan kerja dan perceived organizational support terhadap komitmen organisasi. Dimana hasil yang didapatkan dari penelitian ini mengarahkan bahwa adanya hubungan yang signifikan antara kepuasan kerja, keterlibatan dalam kerja dan perceived organizational support terhadap komitmen organisasi.

Penelitian yang pernah dilakukan oleh Ma'alip, Yahya dan Ain (2012) faktor yang mempengaruhi variabel komitmen organisasi pekerja di Malaysia yaitu variabel lingkungan eksternal, tekanan dalam kerja, kepuasan kerja, dan keinginan untuk pergi. Hasil penelitian menyatakan bahwa kepuasan kerja memiliki pengaruh yang kuat terhadap komitmen organisasi dan keinginan untuk pergi. Berdasarkan penelitian yang telah dilaksanakan oleh Isran, Shah, dan Memon (2012) menganalisa pengaruh kepuasan kerja terhadap komitmen organisasi para anggota Fakultas Universitas sector public yaitu Universitas Sindh dan Universitas Shah Abdul Latif Kahirpur. Bahwa Penelitian tersebut memberikan petunjuk adanya hubungan positif dan signifikan antara kepuasan kerja dan komitmen organisasi. Berdasarksn pernyataan tersebut bahwa kepuasan kerja memiliki pengaruh kepada komitmen seorang karyawan pada organisasi. Jika semakin tinggi kepuasan dalam bekerja maka semakin tinggi juga komitmentnya.

Pada Penelitian yang dilakukan oleh Ramay dan Bashir (2008), peneliti menyatakan bahwa faktor yang mempengaruhi komitmen organisasi karyawan Institute Teknology (IT) di Pakistan yaitu 
kesempatan dalam karir, work life policies dan karakteristik kerja. Pada hasil penelitian memberikan pernyataan bahwa pekerja IT di Pakistan cenderung memilih system kerja yang formal dibandingkan fleksibilitas dalam karakteristik kerja.Penelitian yang pernah dilakukan oleh Norcio dan Liu (2009), dimana peneliti menyatakan bahwa faktor yang mempengaruhi komitmen organisasi adalah kepuasan kerja dan karakteristik kerja. Penelitian menunjukkan hasil bahwa kepuasan kerja dan kakrakterisitk kerja memiliki pengaruh yang signifikan dengan komitmen organisasi. Berdasarkan penelitian lain yang dilakukan oleh Djastuti (2011) yang bertujuan mengetahui pengaruh karakteristik kerja didalamnya termasuk variasi kemampuan, identitas pekerjaan, signifikansi pekerjan, autonomi dan umpan balik terhadap komitmen orgnisasi di perusahaan konstruksi. Bahwa hasil penelitian menyatakan karakteristik kerja karyawan perusahaan kontruksi memiliki pengaruh yang signifikan terhadap komitmen organisasi. Berdasarkan pernyataan tersebut dapat diketahui bahwa karakteristik pekerjaan memiliki pengaruh terhadap komitmen aeorang pekerja di bidang perbankan.

Pada penelitian lain yang telah dilakukan oleh Gunesser dan Erben (2008) dimana penelitian dilakukan untuk melihat dampak kepemimpinan terhadap komitmen organisasi dan etika. Sample yang digunakan sebanyak 142 individu. Hasil dari penelitian menunjukkan bahwa kepemimpinan memberikan memberikan pengaruh signifikan terhadap komitmen organisasi namun tidak memberikan pengaruh signifikan terhadap etika. Pada penellitian yang telah dilakukan oleh Krishman dan Chandra (2009) yang bertujuan untuk mengetahui dampak transformational kepemimpinan dan keyakinan dalam bekerja seperti etika kerja, Marxist, organisasi, etika waktu dan kemanusian terhadap komitmen organisasi. Sample yang dimanfaatkan yaitu 34 manager IT dan manager manufaktur di India, Pada hasil penelitian memberikan bahwa kepemimpinan transformational dan keyakinan dalam bekerja memiliki pengaruh yang signifikan terhadap komitmen organisasi.

Penelitian yang telah dilakukan oleh Watson (2010) yang bertujuan untuk memberikan pengaruh nilai etika karywan dan persepsi karyawan tentang kepemimpinan terhadap komitmen organisasi. Pada penelitian ini menggunakan C.M.I kuesioner kesehatan komitmen organisasi untuk menetukan tingkat dalam komitmen pekerja. Pada hasil penelitian memberikan nilai bahwa etika karywan dan persepsi karyawan tentang kepemimpinan memiliki pengaruh yang signifikan terhadap komitmen organisasi, Bahwa kepemimpinan mampu memberikan pengaruh kepada komitmen karyawan di bidang perbankan. Jika semakin baik kepemimpinan seorang atasan memiliki pengaruh serta kepercayaan kepada pekerja sehingga makin tinggi komitmen pekerja pada suatu organisasi usaha, karyawan merasa layak dan percaya terhadap bank tempat dia bekerja, Dapat disimpulkan bahwa pekerja merasa memliki komitmen yang kuat di organisasi. Bagitu juga sebaliknya, jika semamin kecil kepercayaan serta keyakinan karyawan terhadap atasannya, maka semakin rendah komitmentnya, jika pekerja merasa ragu dan kemungkinan besar mereka berhenti dari pekerjaannya, sehingga disimpulkan bahwa tingkat komitmen organisasi semakin rendah.

Pada Penelitian yang telah dilakukan oleh Chang dan Magoshi (2009) bertujuan mengetahui pengaruh keadilan didalam organisasi terhadap komitmen organisasi di Jepang dan Korea. Seluruh kuesioner yang disebarkan berjumlah 370 responden kepada perusahaan di Korea dan total 212 di perusahaan Jepang. Penelitian akhir menunjukkan bahwa keadilan dalam organisasi memiliki hubungan signifikan terhadap komitmen organisasi. Penelitian yang pernah dilakukan oleh Xia, Liao, Wang dan Chang (2010), yang memberikan pengaruh terhadap komitmen organisasi serta performa kerja yaitu keadilan dalam organisasi. Sebanyak 793 kuesioner disebarkan untuk karyawan industri 
di Republik Cina. Pada hasilnya menunjukkan bahwa keadilan dalam organisasi memberikan pengaruh signifikan terhadap komitmen organisasi dan performa kerja. Selanjutnya pada penelitian yang telah dilakukan oleh Joo, Crow, Lee (2011) bermaksud memberikan pengaruh keadilan didalam organisasi terhadap komitmen organisasi terhadap petugas kepolisian yang terdapat di Korea Selatan. Responden dilaksanakan untuk 418 petugas polisi di Korea Selatan ketika sedang melaksanakan kegiatan pelatihan jasa. Pada hasil yang ditunjukkan bahwa kepemimpinan, keadilan, dalam suatu organisasi dan kepuasan kerja memberikan pengaruh signifikan terhadap komitmen organisasi. Berikutnya penelitian yang telah dilakukan juga oleh Kathairi dan Suliman (2013) bertujuan memberikan hubungan antara keadilan dalam organisasi, komitmen organisasi dan performa kerja di negera-negara berkembang. Responden sebanyak 500 karyawan full-time di Negara Uni Emirat Arab. Hasil Penelitian menunjukan bahwa keadilan dalam organisasi memberikan pengaruh yang signifikan terhadap komitmen organisasi dan performa kerja di Negara-negara berkembang. Atas pernyataan tersebut diberikan penyataan bahwa keadilan dalam organisasi memberikan pengaruh kepada komitmen seorang pekerja didalam bidang perbankan. Jika tingginya keadilan yang terjadi di bank semakin tinggi pula komitmen pekerja di sebuah perbankan,jika pekerja merasa diperlakukan secara adil oleh atasannya, pekerja merasa layak dan percaya dimana tempat mereka bekerja, maka disimpulkan pekerja akan semakin tinggi tingkat komitmen organisasinya. Jika semakin rendah keadilan yang didapatkan di sebuah bank, akan semakin rendah komitmen karyawan, karena jika pekerja diperlakukan secara tidak adil oleh atasannya maupun bank dimana mereka bekerja maka pekerja akan ragu dan besar kemungkinan akan berhenti kerja,maka disimpulkan tingkat komitmen organisasi dapat semakin rendah. Jika memperhatikan penjelasan dari penelitian terdahulu, hipotesa yang diujikan pada penelitian tersebut adalah sebagai berikut:

H1: Kepuasan Kerja berpengaruh signifikan positif terhadap komitmen organisasi karyawan Bank

H2: Motivasi Kerja berpengaruh signifikan positif terhadap komitmen organisasi karyawan Bank

H3: Karakteristik Kerja memiliki pengaruh signifikan positif terhadap komitmen organisasi Karyawan Bank

H4: Kepemimpinan memiliki pengaruh signifikan positif terhadap komitmen organisasi Karyawan Bank

H5: Keadilan dalam organisasi memiliki pengaruh signifikan positif terhadap komitmen Organisasi karyawan Bank

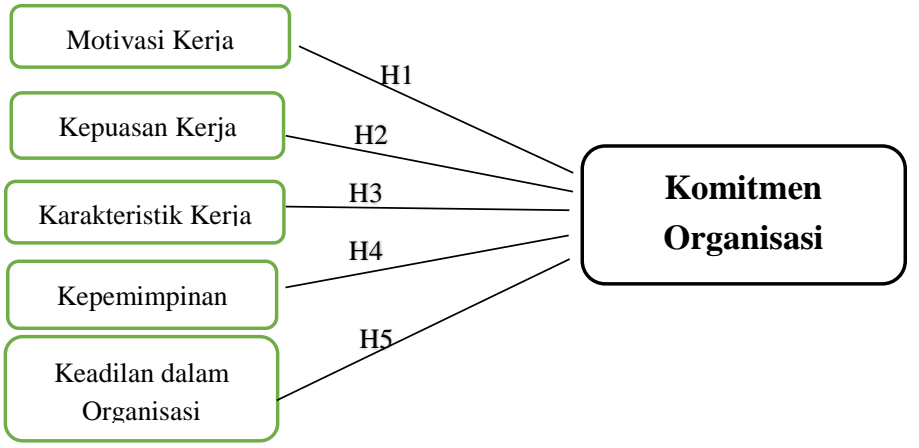

Gambar 1. Model Penelitian, Sumber: Ali, Asghar, Khan,Razi (2011), Jackson, Naumann, Widmier (2000) Armeli,Eieberger,Rhoades (2001),\& Erben dan Guneser (2008) 


\section{METODE}

Populasi dalam penelitian ini adalah karyawan perbankan. Sample yang digunakan adalah para pekerja yang terdapat di 5 (lima) perbankan swasta dengan jumlah karywan terbanyak. Begitu banyaknya pertumbuhan perbankan di Batam, Bank swasta ataupun Bank Perkreditan Rakyat yang menyerap tenaga kerja semakin banyak di Batam khususnya di bidang perbankan, hal inilah yang membuat untuk memilih bank sebagai objek penelitian. Perbankan yang dijadikan sample adalah karyawan Bank CIMB Niaga, Bank Panin, Bank Danamon, Bank Central Asia, serta Bank OCBC NISP. Hal ini disebabkan 5 (lima) Bank tersebut yang menyerap tenaga kerja terbanyak di Batam (Disnaker 2017), penulis memilih perbankan karena saat ini Batam merupakan daerah di Indonesia yang terus berkembang dengan makin banyak bertambahnya bank swasta dan Bank Perkreditan Rakyat, serta lembaga keuangan lainnya. Namun banyaknya perbankan dan lembaga keuangan lainnya juga tidak menurunkan tingkat turn over karyawan di bidang perbankan. (www.pwc.com.id)

Tingkat perkembangan perbankan yang sangat signifikan terlihat pada 5 (lima) tahun terakhir, perkembangan yang positif di bidang perbankan terlihat pada tingkat lending atau pinjaman yang cukup tinggi serta inovasi produk yang semakin baik, seperti produk derivative misalnya credit linked notes, begitu juga kerjasama dengan produk funding atau simpanan berupa reksadana serta bancasurance. Pada metode pengambilan sample dilakukan dengan purposive sampling, dimana metode pemilihan sample secara tidak acak, informasi dengan menggunakan kriteria tertentu. (Supomo dan Indriantoro, 2002).

Pada tingkat penelitian ini dilakukan pengujian dengan model Partial Last Squares (PLS), kita ketahui bahwa PLS adalah model persamaan dari Structural Equation Modeling (SEM) berbasis komponen atau varian. Menurut Ghozli (2012), PLS adalah pendekatan alternative yang tergeser dari pendekatan SEM yang berbasis kovarian berubah menjadi basis varian. PLS lebih bersifat predictive model ini adalah metode analisis powerfull, sedangkan SEM menguji kualitas teorinya. PLS dapat digunakan untuk menjelaskan ada tidaknya hubungan antar variabel laten dan dapat menganalisa konstruksi yang dibuat melalui indicator reflektif dan formatif.

\section{HASIL DAN PEMBAHASAN}

Pada Tingkat uji validitas dilaksanakan untuk mengukur akurasi dari beberapa pertanyaan dalam kuesioner, dimana data yang memiliki nilai muatan score factor loading lebih besar 0.3 ini menjadi nilai data yang valid. Data yang di ujikan menjelaskan bahwa semua pernyataan adalah valid, sebab memiliki score factor loading lebih besar dari 0.3. Pada tingkat pengujian reliabilitas dilaksanakan untuk melihat konsistrnsi dari hasil kuesioner. Hasil nilai dari Cronbach's coefficient alpha yang dapat diterima yaitu lebih besar dari atau sama dengan 0.6 dengan hasil uji yang menunjukkan semua

Pada hasil pengujian path analysis terdapat nilai T-Statistics variabel kepuasan kerja lebih kecil dari 1.96 membuat variabel karakteristik kerja tidak mempunyai pengaruh yang signifikan tehadap komitmen organisasi (Hair et al. 2011) Tingkat pengaruh yang tidak signifikan kemungkinan disebabkan karena karywan yang tidak masalah dengan karekteristik pekerjaan yang mereka terima.

Pada hasil pengujian path analysis terdapat nilai T-Statistics variabel kepuasan kerja lebih besar dari 1.96 membuat variabel kepuasan kerja memiliki pengaruh yang signifikan terhadap pergantian kerja karyawan. (Hair et al 2011). Tingkat pengaruh signifikan positif tersebut dapat disebabkan 
karena kepuasan kerja karywan yang diterima pada tempat kerja sehingga mendorong karywan untuk dapat meningkatkan kinerja serta komitmen dalam organisasi.

Pada hasil pengujian path analysis terdapat nilai T-Statistics variabel Kepemimpinan lebih kecil dari 1.96 membuat variabel kepemimpinan tidak memiliki pengaruh yang signifikan terhadap komitmen organisasi (Hair et al, 2011). Tingkat pengaruh yang idak signifikan disebabkan pekerja yang tidak menjadi masalah perlakuan yang diberikan pihak manajer kepada pekerja.

Pada hasil pengujian path analysis terdapat nilai T-Statistics variabel Keadilan didalam organisasi lebih kecil dari 1,96 dimana variabel keadilan dalam organisasi tidak mempunyai pengaruh yang signifikan terhadap komitmen organisasi (Hair etal, 2011) Pengaruh yang tidak signifikan kemungkinan dikarenakan oleh karyawan yang tidak menjadikan masalah perlakuan yang disampaikan oleh perusahaan dan rasa keadilan yang mereka terima selama bekerja.

Pada hasil pengujian path analysis terdapat nilai T-Statistics variabel Motivasi Kerja lebih besar dari 1,9 sehingga variabel motivasi kerja memberikan pengaruh signifikan positif tersebut dikarenakan dorongan yang menimbulkan semangat kerja setiap karyawan serta kepuasan yang mereka terima ditempat kerja menyebabkan karyawan lebih memilih motivasi untuk kontribusi, dan dapat memberikan komintment organisasi yang lebih tinggi.

Pada hasil pengujian $R$ Square sebesar 0,7877 dimana maksudnya adalah variabel endogen (independen) motivasi kerja,kepuasan kerja, karakteristik kerja, kepemimpinan dan keadilan dalam organisasi dapat memberikan penjelasan variabel eksogen (dependen) komitmen organisasi sebesar $78,77 \%$ sementara untuk 21,33\% lainnya dapat dijelaskan oleh variabel lain yang tidak dapat dipakai dalam penelitian ini. Nilai GoF yang ditimbulkan juga lebih besar dari 0,36,maka dapat tersimpulkan bahwa GoF termasuk dalam ketegori besar yang maksudnya model tersebut baik dan dapat digunakan dalam penelitian (Fornel \& Larcker,1981; Cohen 198; Ghozali \& Latan 2012).

\section{KESIMPULAN}

Berdasarkan hasil penelitian dapat disimpulkan: a) Hasil uji pada hipotesis H1 diperoleh bahwa Kepuasan Kerja berpengaruh signifikan positif pada komitmen organisasi, b) Hasil uji pada hipotesis H2 diperoleh bahwa Motivasi Kerja berpengaruh signifikan positif terhadap komitmen organisasi, c) Hasil uji pada hipotesis H3 diperoleh bahwa Karekteristik Kerja tidak berpengaruh signifikan positif terhadap komitmen kerja, d) Hasil uji hipotesis $\mathrm{H} 4$ diperoleh bahwa Kepemimpinan tidak berpengaruh signifikan positif terhadap komitmen organisasi, e) Hasil uji hipotesis H5 diperoleh bahwa Keadilan tidak berpengaruh signifikan positif terhadap komitmen organisasi.

Adapun keterbatasan dalam penelitian ini adalah sebagai berikut: a) Hasil nilai pengujian $R$ Square job satisfaction, work motivation, job characteristic, leadership dan orgnanizational justice sebesar 0,7877 atau 78,77\% menyatakan bahwa variabel organizational commitment tidak dapat sepenuhnya dijelaskan oleh variabel job satisfaction, work motivation dan job characteristic, leadership dan organizational justice; b) Tehnik Pengumpulan Data menggunakan metode survey melalui kuesioner yang memiliki kelemahan dimana persepsi yang disampaikan responden selayaknya belum sebenarnya terhadap kondisi yang ada; c) Penelitian ini dikerjakan terbatas hanya pada 5 (lima) bank dengan jumlah dan kapasitas karywan terbanyak yang hanya ada di Batam Rekomendasi. 
Hasil penelitian memberikan kesempatan yang sangat luas untuk peneliti selanjutnya seperti antara lain: a) Hasil pengujian nilai $R$ Square job satisfaction,work motivation, job characteristic, leadership dan organizational justices sebesar 0,7877 atau 78,77\% menunjukkan bahwa variabel organizational commitment tidak sepenuhnya dijelaskan oleh variabel job satisfaction, work mitivation dan job characteristic, leadership dan organizational justice, sedangkan 21,33 \% dijelaskan oleh variabel lain seperti employee participation, role clarity (Bhatti \& Nawab 2011), job experience (Tahere, Zahra, Fateme \& Asma 2012), demographic factor, emotional intelligent, career salience, achievement motivation (Salami 2008), locus control (Igbneghu 2011), job involment, perceived organizational support (Kamaruddin salim dan Kadir 2012), ekternal environment, occupational stress, intention to leave (Yahya, Ma'alip \& Ain 2012), career opportunities dan work life policies ( Bashir \& Ramay 2008) maka direkomendasikan untuk meneliti variabel lain yang mempengaruhi variabel dependen; b) Objek untuk rekomendasi penelitian selanjutnya sebaiknya tidak hanya meneliti pada sector industry bank saja, namun dapat juga dilaksanakan pada bidang lembaga keuangan lainnya. Untuk responden selanjutnya tidak hanya dilakukan di Batam saja, tetapi dapat juga dilaksanakan dikota lainnya agar dalam estimasi untu parameter populasi dapat secara akurat dan hasil yang didapatkan juga dapat hasil yang tepat.

\section{DAFTAR PUSTAKA}

Bashir, S. \& Ramay, M. I. (2008). Determinants of Organizational Commitment A Study of Information Technology Professionals in Pakistan.Institute of behavioral and Applied Management. 226-238.

Bhatti, K. K., Nawab, S., Akbar, A. (2011). Effect of Direct Participation on Organizational Commitment. International Journal of Business and Social Science. Vol. 2 No. 9, 15-23.

Boles, J.,Madupalli, R., Rutherford, B., Wood, J. A. (2007). The relationship of facets of salesperson job satisfaction with affective organizational commitment. Journal of business \& Industrial Marketing. Vol. 25 (5), 311-321.

Chughtai, A. A.\& Zafar, S. (2006). Antecendents and Consequences of Organizational Commitment Among Pakistani University Teachers. Applied H.R.M. Journal. Vol. 11, No. 1, 39-64.

Choong, Yuen-Onn., Wong, Kee-Luen., Lau, Teck-Chai. (2011). Intrinsic Motivation and Organizational Commitment in The Malaysian Private Higher Education Institutions: An Empirical Study. Journal of Art, Science \& Commerce. Vol. II (4).

Curtis, Susan \& Wright. (2001). Retaining Employees. The Fast Track to Commitment, Management Research News. Volume 24.

Djastuti, I. (2010). The Influence of Job Characteristics On Job Satisfaction, Organizational Commitment and Managerial Performance. JurnalManajemenBisnis.Vol. 3, No. 2.

Erben, G. S.\&Guneser, A. B. (2008).The Relationship Between Paternalistic Leadership and Organizational Commitment: Investigating the Role of Climate Regarding Ethics. Journal of Business Ethics. Vol. 82, 955-968.

Ghozali, I., \&Latan, H. (2012). "Partial Least Squares : Konsep, Teknik dan Aplikasi Menggunakan Program Smart PLS 2.0 M3”, Badan Penerbit Universitas Diponegoro, Semarang-Jawa Tengah. 
Hair, J. F. Jr. et al. (2011).Multivariate Data Analysis, (5 ${ }^{\text {Th }}$ Edition). Upper Saddle River, NJ : Prentice Hall.

Haryanto, T. \& Sriwidodo, U. (2009). Pengaruh Karakteristik Personal, Karakteristik Kerja dan Pengalaman Kerja Terhadap Komitmen Organisasi. Jurnal Manajemen Sumberdaya Manusia. Vol. 3, No. 1.

Hassan, A. (2002). Organizational Justice As A Determinant of Organizational Commitment and Intention to Leave. Assian Academy of Management Journal. Vol. 7, No. 2, 55-66.

Igbeneghu, B. I. (2011). Influence of Locus of Control and Job Satisfaction on Organizational Commitment: A Study of Medical Records Personnel in University Teaching Hospitals in Nigeria. Library Philosophy and Practice.

Indriantoro, N., dan Supomo, B. (1999). Metodologi Penelitian Bisnis: Untuk Akuntasi dan Manajemen. Badan Penerbit Fakultas Ekonomi. Yogyakarta.

Kanchana, P. Na. \& Panchanatham, N. (2012).Analytical Study on Organizational Commitment with Reference to Tamil Nadu Papers Limited, Kagidapuram, Karur District. International Journal of Multidisciplinary Research.Vol 2 (1),90-107.

Khan, H.,Razi, A., Ali, S. A.,Asghar, A. (2011).A study on Relationship between Organizational job Commitment, and its Determinants among CSRs and Managerial level Employees of Pakistan (Telecommunication sector). Interdisciplinary Journal of Contemporary Research in Business. Vol. 3 No. 8, 271-284.

Lin, S. C.\& Lin, J. S. J. (2011). Impacts of Coworkers' relationships on organizational commitment and intervening effects on job satisfaction.African Journal of Business Management. Vol. 5 (8), 3396-3409.

Liu, S. W.\&Norcio, R. (2009).The Combination Predictor Model of Organizational Commitment.The Journal of Human Resource and Adult Learning. Vol.5, Num. 1.

Malik, M. M., Nawab, S.,Naeem, B. (2010). Job Satisfaction and Organizational Commitment of University Teachers in Public Sector of Pakistan. International Journal of Business and Management. Vol. 5, No. 6, 17-26.

Magoshi, E.,\& Chang, E. (2009).Diversity management and the effects on employees' organizational commitment: Evidence from Japan and Korea. Journal of World Business. 44, 31-40.

Noor, A. (2009). Examining Organizational Citizenship Behavior as The Outcome of Organizational Commitment: A Study of Universities Teachers of Pakistan. CRBC.

Nunnally, J.C., \& Bernstein, I.H. (1994).Psychometric Theory, $3^{\text {rd }}$ edition, McGraw-Hill, New York

Raza, M. A.,\& Nawaz, M. M. (2011). Impact of Job Enrichment on Employees' Job Satisfaction, Motivation and Organizational Commitment: Evidence From Public Sector of Pakistan. European Journal of Social Sciences.Volume 23, Number 2.

Robbins, S. P., \& Judge, T. (2007).Organizational Behaviour among Human Resource Department.Economic and Management. 
Samad, S. (2011).The Effects of Job Satisfaction on Organizational Commitment and Job Performance Relationship: A Case of Managers in Malaysia's Manufacturing Companies. EuropeanJournal of Social Science.Vol. 18, No. 4.

Shah, S. M. A., Jatoi, M. M., Memon, M. S. (2012). The Impact of Employees' Job Satisfaction on the Organizational Commitment: A Study of Faculty Members of Private Sector Universities of Pakistan. Interdisciplinary Journal of Contemporary Research In Business. Vol 3, No 11.

Shahnawaz, M. G.\& Jafri, M. H. (2009).Psychological Capital as Predictor of Organizational Commitment and Organizational Citizenship Behaviour.Journal of the Indian Academy of Applied Psychology. Vol. 35, 78-84.

Simmons, E. S. (2005). Predictors of Organizational Commitment Among Staff in Assisted Living. The Gerontological Society of America. Vol. 45, No. 2, 196-205.

Tahere, N., Zahra, G. T.,Fateme, D.,Asma, Y. J. (2012). Investigating the Effects of Job Experience, Satisfaction and Motivation on Organizational Commitment Case Study: The Nurses of Ghaem Hospital in Masshad, Iran. Research Journal of Recent Sciences.Vol. 1(7), 59-67.

Warsi, S., Fatima, N.,\&Sahibzada, S. A. (2009). Study on Relationship Between Organizational Commitment and Its Determinants Among Private Sector Employees of Pakistan. International Review of Business Research Papers.Vol.5, No. 3, 399-410.

Watson, T. (2010).Leader Ethics and Organizational Commitment.ULR. Vol. III (1), 16-26.

Wu, T. F., Tsai, M. H., Fey, Y. H., Wu, R. T. Y. (2006). A Study of the Relationship between Manager's Leadership Style and Organizational Commitment in Taiwan's International Tourist Hotels.Asian Journal of Management and Humanity Sciences. Vol. 1, No. 3, 434-452.

Yahaya, N., Ma'alip, A. Y. H., Ain, S. H. S. N. (2012). The Predictor of External Environment, Occupational Stress, Job Satisfaction and Inten to Leave Towards Organizational Commitment. Archives Des Sciences.Vol. 65, No. 3.

Ziauddin, Khan, M. R., Jam, F. A.,Hijazi, S. T. (2010). The Effects of Employees Job Stress on Organizational Commitment.EuropeanJournal of Social Science.Vol. 13, No. 4.

Zurnali. (2010). Learning Organization, Competency, Organizational Commitment, dan Customer Orientation: Knowledge Worker - KerangkaRisetManajemenSumberdayaManusia di Masa Depan. Unpad Press, Bandung.

\section{UCAPAN TERIMA KASIH}

Terima kasih penulis ucapankan kepada rekan kerja, mahasiswa, dan LPPM Universitas Internasional Batam, atas support dan kerjasama dalam penelitian ini, selain itu juga rekan mahasiswa pada program Doktoral angkatan VIII dan angkatan IX di Usakti Jakarta. Semoga dapat terus belajar dan tidak pernah berhenti untuk menuntut ilmu. 


\section{PROFIL PENULIS}

Penulis adalah, seorang konsultan pendidikan di beberapa sekolah menengah atas dan kejuruan di Batam. Traine juga motivator Dosen selama +/- 13 tahun dan juga sebagai mahasiswa tingkat akhir yang sedang menyelesaikan desertasi untuk mendapatkan gelar Doktor konsentrasi Manajemen Strategik. 